\title{
Seed Geometry in the Vitaceae
}

\author{
Emilio Cervantes ${ }^{1, *(\mathbb{C}}$, José Javier Martín-Gómez ${ }^{1}\left(\mathbb{D}\right.$, Diego Gutiérrez del Pozo ${ }^{2}\left(\mathbb{C}\right.$ and Ángel Tocino ${ }^{3} \mathbb{C}$ \\ 1 Instituto de Recursos Naturales y Agrobiología del Consejo Superior de Investigaciones \\ Científicas (IRNASA-CSIC), Cordel de Merinas, 40, 37008 Salamanca, Spain; jjavier.martin@irnasa.csic.es \\ 2 Departamento de Conservación y Manejo de Vida Silvestre (CYMVIS), Universidad Estatal \\ Amazónica (UEA), Carretera Tena a Puyo Km, 44, Puyo 150950, Ecuador; diego.gutierrez.pozo@gmail.com \\ 3 Departamento de Matemáticas, Facultad de Ciencias, Universidad de Salamanca, Plaza de la Merced 1-4, \\ 37008 Salamanca, Spain; bacon@usal.es \\ * Correspondence: emilio.cervantes@irnasa.csic.es
}

Citation: Cervantes, E.;

Martín-Gómez, J.J.; Gutiérrez del

Pozo, D.; Tocino, Á. Seed Geometry in the Vitaceae. Plants 2021, 10, 1695.

https://doi.org/10.3390/plants10081695

Academic Editor: Eleftherios

P. Eleftheriou

Received: 9 July 2021

Accepted: 10 August 2021

Published: 18 August 2021

Publisher's Note: MDPI stays neutral with regard to jurisdictional claims in published maps and institutional affiliations.

Copyright: (c) 2021 by the authors. Licensee MDPI, Basel, Switzerland. This article is an open access article distributed under the terms and conditions of the Creative Commons Attribution (CC BY) license (https:/ / creativecommons.org/licenses/by/ $4.0 /)$.

\begin{abstract}
The Vitaceae Juss., in the basal lineages of Rosids, contains sixteen genera and 950 species, mainly of tropical lianas. The family has been divided in five tribes: Ampelopsideae, Cisseae, Cayratieae, Parthenocisseae and Viteae. Seed shape is variable in this family. Based on new models derived from equations representing heart and water drop curves, we describe seed shape in species of the Vitaceae. According to their similarity to geometric models, the seeds of the Vitaceae have been classified in ten groups. Three of them correspond to models before described and shared with the Arecaceae (lenses, superellipses and elongated water drops), while in the seven groups remaining, four correspond to general models (waterdrops, heart curves, elongated heart curves and other elongated models) and three adjust to the silhouettes of seeds in particular genera (heart curves of Cayratia and Pseudocayratia, heart curves of the Squared Heart Curve (SqHC) type of Ampelocissus and Ampelopsis and Elongated Superellipse-Heart Curves (ESHCs), frequent in Tetrastigma species and observed also in Cissus species and Rhoicissus rhomboidea). The utilities of the application of geometric models for seed description and shape quantification in this family are discussed.
\end{abstract}

Keywords: endosperm; geometry; morphology; seed shape; Vitaceae

\section{Introduction}

The Vitaceae Juss. contains sixteen genera with ca. 950 species of lianas primarily distributed in the tropics with some genera in the temperate regions. The Leeaceae Dumort., with a single genus of 34 species, mostly shrubs and small trees rather than lianas, included in the family in the APG IV [1], was later recognized as a separate family [2,3]. Both families constitute the order Vitales, one of the basal lineages of Rosids, whose closest relative remains controversial $[4,5]$.

The Vitaceae has been divided in five tribes [3] (Table 1): (I) Ampelopsideae J. Wen and Z. L. Nie (Ampelopsis Michx., Nekemias Raf., Rhoicissus Planch., Clematicissus Planch.); (II) Cisseae Rchb. (Cissus L.); (III) Cayratieae J.Wen and L.M.Lu (Cayratia Juss. Ex Guill, Causonis Raf., Acareosperma Gagnep., Afrocayratia, Cyphostemma (Planch.) Alston, Pseudocayratia J.Wen, L.M.Lu and Z.D.Chen, Tetrastigma Planch.); (IV) Parthenocisseae J.Wen and Z.D.Chen (Parthenocissus Planch.) and (V) Viteae Dumort (Ampelocissus Planch., and Vitis L.). Cayratia and Cyphostemma were included in Cissus by Linné and Planchon considered the former as a section of Cissus [6,7].

Cissus is the largest genus in the family with 300 species of complex classification [8]. Cyphostemma is second, with 200 species of an interesting diversity in their range of distribution as well as in growth habits (vines and lianas, herbs, stem succulents and a tree) [9]. Vitis has seventy-five inter-fertile wild species distributed in three continents under subtropical, Mediterranean and continental-temperate climatic conditions. Vitis vinifera L. is the species with highest economic importance in the family with some taxonomic uncertainty about the differentiation between $V$. vinifera L. subsp. vinifera and V. vinifera L. subsp. sylvestris 
(Willd.) Hegi [10,11]. Thousands of cultivars of $V$. vinifera are used worldwide in Viticulture. Species of other genera are widely cultivated, such as Parthenocissus quinquefolia (L.) Planch., the Virginia creeper, in temperate areas, and Cissus incisa Des Moul., the grape ivy, in tropical areas. Species of the genus Tetrastigma are the only host plants for the parasitic plant Rafflesia arnoldii R.Br., Rafflesiaceae, which is native only to a few areas within the Malay Archipelago [12].

Table 1. A summary of the taxonomy of the Vitaceae. The approximate number of species in each tribe and genus is given between parentheses. Data adapted from [3].

\begin{tabular}{cc}
\hline Tribe & Genera \\
\hline I. Ampelopsideae (47) & Ampelopsis Michx. (18) \\
Nekemias Raf. (9) \\
Rhoicissus Planch. (14) \\
Clematicissus Planch. (6) \\
Cissus L. (300) \\
Cayratia Juss. (25) \\
III. Cayratieae (368) \\
Causonis Raf. (30) \\
Acareosperma Gagnep. (1) \\
Afrocayratia (7) \\
Cyphostemma (Planch.) Alston (200) \\
IV. Parthenocisseae (16) \\
Pseudocayratia J. Wen, L.M.Lu and Z.D. Chen (5) \\
Tetrastigma (Miq.) Planch. (100) \\
Parthenocissus Planch. (14) \\
Yua C.L.Li (2) \\
Ampelocissus Planch. (115) \\
Vitis L. (75)
\end{tabular}

The taxonomy and phylogenetic relationships of the Vitaceae are far from complete and will benefit from an accurate description of seeds in the unambiguous terms of geometry. From a practical point of view, the classification based on geometric models may contribute to the distinction between wild and crop grapes of Vitis vinifera [11].

The main objective of this review is to provide a framework for the description of seed morphology in the Vitaceae based on geometric models. A recent review of this subject in the Arecaceae described morphological types in the seeds of this family based on the similarity of seed images to geometric figures, like ellipses, ovals and others [13]. Members of both families, the Arecaceae and the Vitaceae, were present in the Neotropical flora in the Eocene [14], and the description of their seeds may serve as a model to develop this work in other plant families.

\section{Seed Morphology in the Vitaceae}

\subsection{Quantification of Seed Shape by Geometric Models}

The silhouettes of bi-dimensional images of seeds often resemble geometric figures that can be used as models for the description and quantification of seed shape in plant families. A recent review of the geometry of seeds in the Arecaceae described a series of models useful for the analysis of seed shape in this family [13]. Geometric models included the ellipses (the circle is a particular type of ellipse), ovals, lemniscates, superellipses, cardioid and derivatives, lenses and the water drop curve [13]. The reader is referred to this review for the algebraic description of the models and their application in the morphometry of seeds in the Arecaceae. The application of geometric models in morphometry is based on the comparison of bi-dimensional images of well oriented seeds with these figures by means of image programs working in two layers (Adobe Photoshop, Corel Photo Paint ... ). The two images (seed and model) can be superimposed searching for a maximum similarity and the ratio between shared and total surface areas, that we have termed $J$ index, is calculated with the data obtained in ImageJ [15]. J index measures the percent of similarity between two images (the seed and the model) and provides information 
on overall seed shape [16,17]. Bidimensional seed images of many plant species adjust well to one of three morphological types: the ellipse, the oval and the cardioid [18]. The seeds of the model plant Arabidopsis thaliana (L.) Heynh., those of the model legumes Lotus japonicus (Regel) K.Larsen and Medicago truncatula Gaertn., as well as the seeds of Capparis spinosa L., in the Capparaceae and Rhus tripartita DC. in the Anacardiaceae adjust well to cardioids or modified cardioids [19-23]. The seeds of Ricinus communis L. and Jatropha curcas L. in the Euphorbiaceae and those of cultivars of Triticum sp. in the Poaceae adjust well to ellipses of varied $x / y$ ratio [24-26]. Oval shaped seeds occur frequently in the Cucurbitaceae, Berberidaceae, Eupteleaceae and Lardizabalaceae $[27,28]$, while the cardioid is more common in Papaveraceae [28]. A given geometric type is sometimes associated with other morphological or ecological characteristics. For example, cardioidtype seeds were observed to be more frequent in small-sized seeds, while elliptic shape is more frequent in larger seeds [18]. In the Malvaceae, cardioid type seeds are associated with small herbs of annual cycle [29].

\subsection{Seed Morphology in the Vitaceae}

The seeds of the Vitaceae share structural characteristics. The endosperm presents in transversal section a typical " $\mathrm{M}$ " shape coincident with a pair of ventral in-folds and a dorsal chalaza knot allowing the identification of fossil seeds in this family [30].

For the application of morphology in taxonomy, characters of the seeds are selected and compared between different taxonomic groups. Frequently, the data concern measurements of defined structural components and the distances between well referenced seed positions. The results depend on the characters selected and the method used for comparison. Chen and Manchester applied successive PCA based on 57 characters to 252 seeds representative of 238 species belonging to 15 genera [31]. The conclusions were: (1) The seeds of Leea, Cissus, Cyphostemma, Tetrastigma, Rhoicissus, and Cayratia have a long or linear chalaza, visible from the ventral side and terminated very near the beak at the dorsal side, a condition that was termed "perichalaza" [32], whereas the seeds in the rest of the family usually have an oval chalaza, central in the dorsal position; (2) Tetrastigma and species of Rhoicissus have peculiar characteristics in their linear chalaza, which is located near the apical notch and extends their beak; their long, narrow, sometimes divergent ventral in-folds and their rugose surface. The authors conclude that, by comparison of selected sets of characters, the seeds can be distinguished to the generic level [31].

Seed shape in the Vitaceae is variable and seeds resembling geometric figures are frequent in this family. The seeds of Ampelocissus are pyriform, oval, or round in dorsal or ventral view [30]. The seeds of Cissus species are often described as globose with a pointed base, elliptic in outline or oblong (see, for example, [33-35]). These adjectives and other like sub-globose or terete are also applied to seed descriptions in other genera suggesting two important points: (1) The seeds of the Vitaceae are suitable for the comparison with geometric figures used as models. (2) The comparison may be quantitative, yielding measures that contribute to taxonomy. Table 2 contains a list of 131 species in the Vitaceae whose seeds have been observed for this work. 
Table 2. A summary of the 131 species for which seed shape has been analysed in this work.

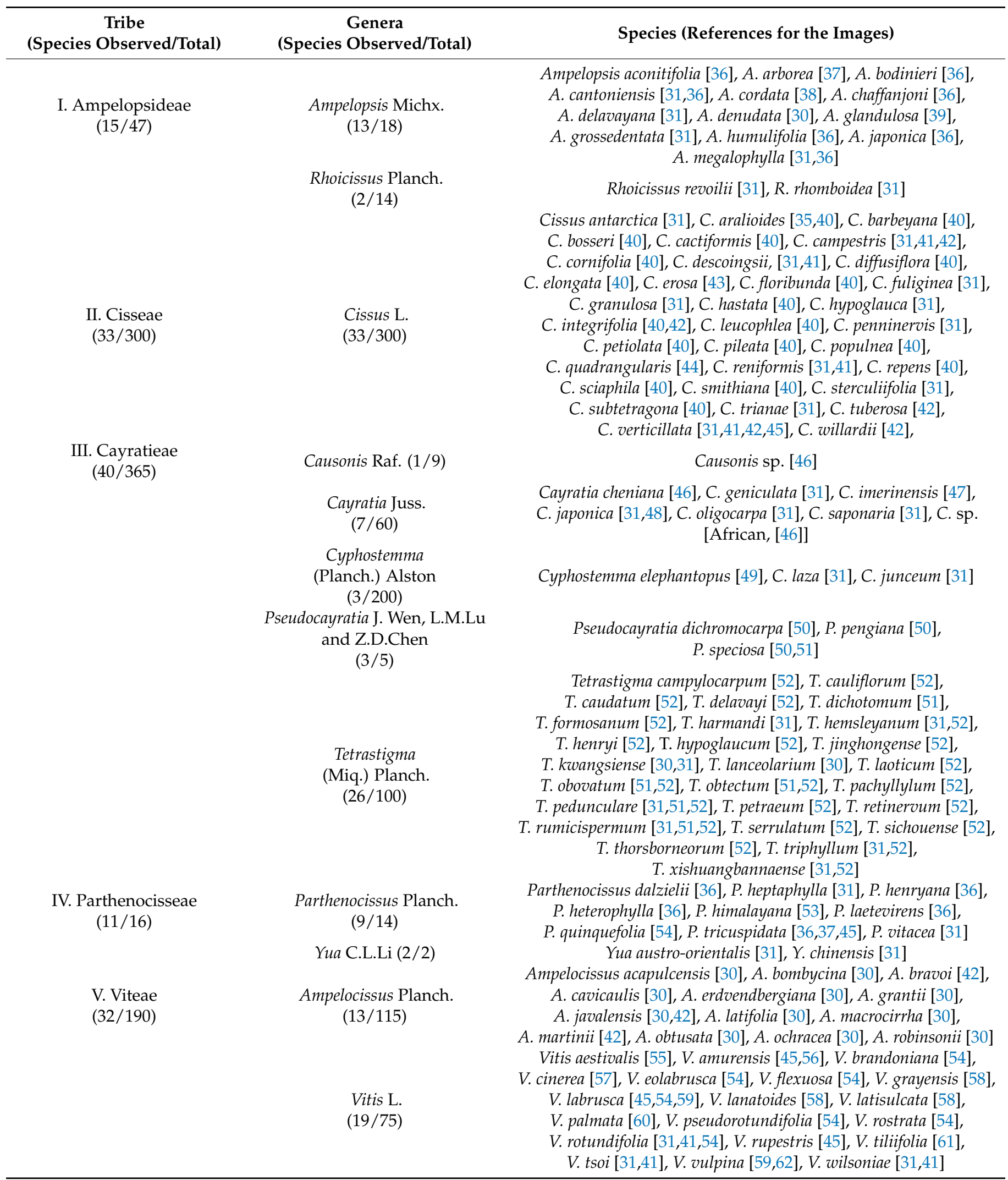

Seven geometric models for the description and quantification of seed shape in the Vitaceae were described before [45]. Models 1 to 5 were derived from modifications in the equations of the heart curve [63], Model 6 was derived from the pyriform curve [64], and 
Model 7 was obtained by the modification of two independent equations representing an ellipse, searching for the similarity with the seeds of cultivars of $V$. vinifera. In subsequent work, Model 7 revealed particularly useful, because models derived from it adjusted well to the shape of many cultivars of V. vinifera in the Spanish collection at IMIDRA [65]. The following section contains a description of new models obtained for this work and their examples in the Vitaceae. The first part presents geometric models shared by the Arecaceae and the Vitaceae, while the second part contains the description of new models based on a series of equations derived from the equation of an ellipse that apply to species in the Vitaceae.

\section{Geometric Models for Seed Description and Quantification in the Vitaceae}

\subsection{Models Shared with the Arecaceae}

The comparison of well-oriented seeds with geometric figures reveals the diversity of shapes in a family, adds precision to the description and permits quantification of seed shape. The geometric analysis of seed shape in the Vitaceae shows a variety of forms shared with the Arecaceae, such as lenses, superellipses and water drops [13], while their combination is not frequent in other plant families.

Lenses and superellipses [13] can be derived from the same formula:

$$
\left|\frac{x}{a}\right|^{p}+\left|\frac{y}{b}\right|^{q}=1
$$

with $p, q>2$ for superellipses and $p>2,1<q<2$ for lenses [66,67]; (see Data Availability Statement section).

Figure 1 presents examples of seeds whose images resemble lenses of different length/width ratios: Cissus sterculiifolia [31], Tetrastigma petraeum [51] and Cissus quadrangularis [44].

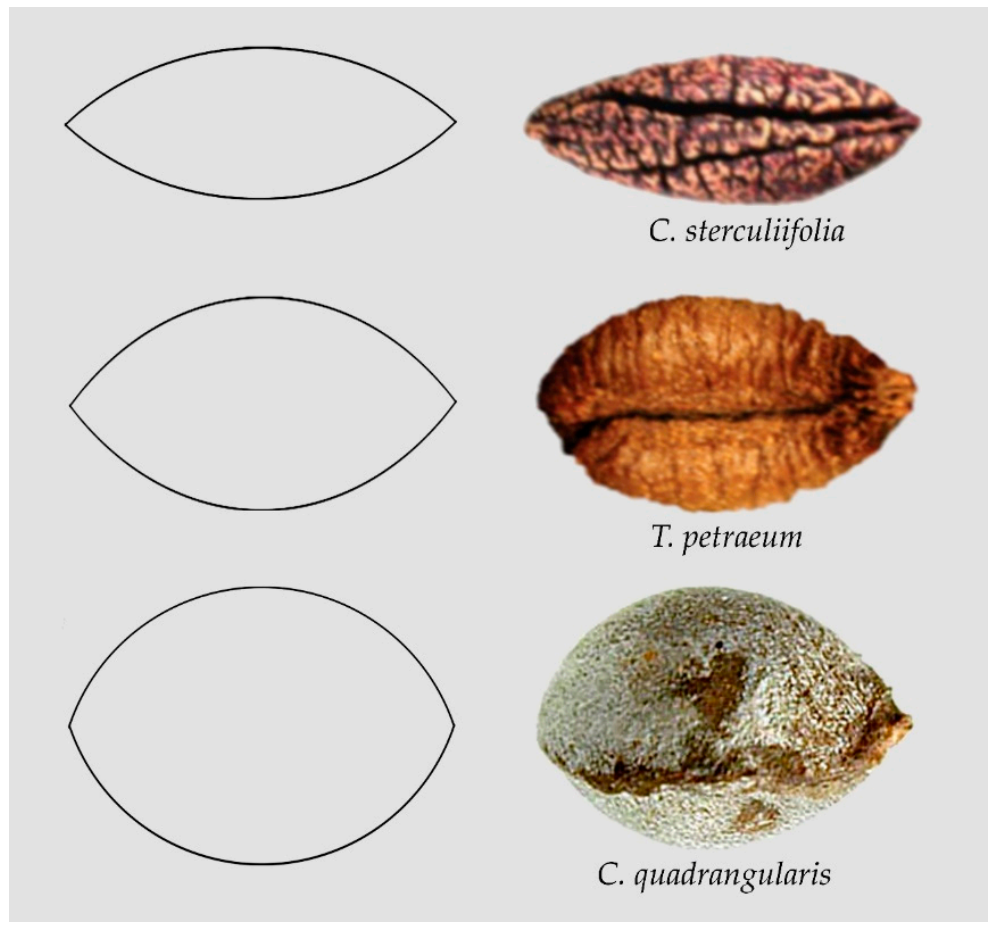

Figure 1. The images of seeds of Cissus sterculiifolia [31], Tetrastigma petraeum [51] and Cissus quadrangularis [44] resemble lenses of different proportions. 
The seeds of Cissus reniformis, Cyphostemma laza and Ampelocissus bravoi adjust to superellipses of different proportions (not shown). Additionally, in some Tetrastigma species the seeds resemble superellipses, for example: Tetrastigma henryi [52], Tetrastigma campylocarpum [51] and T. caudatum [51] (Figure 2).

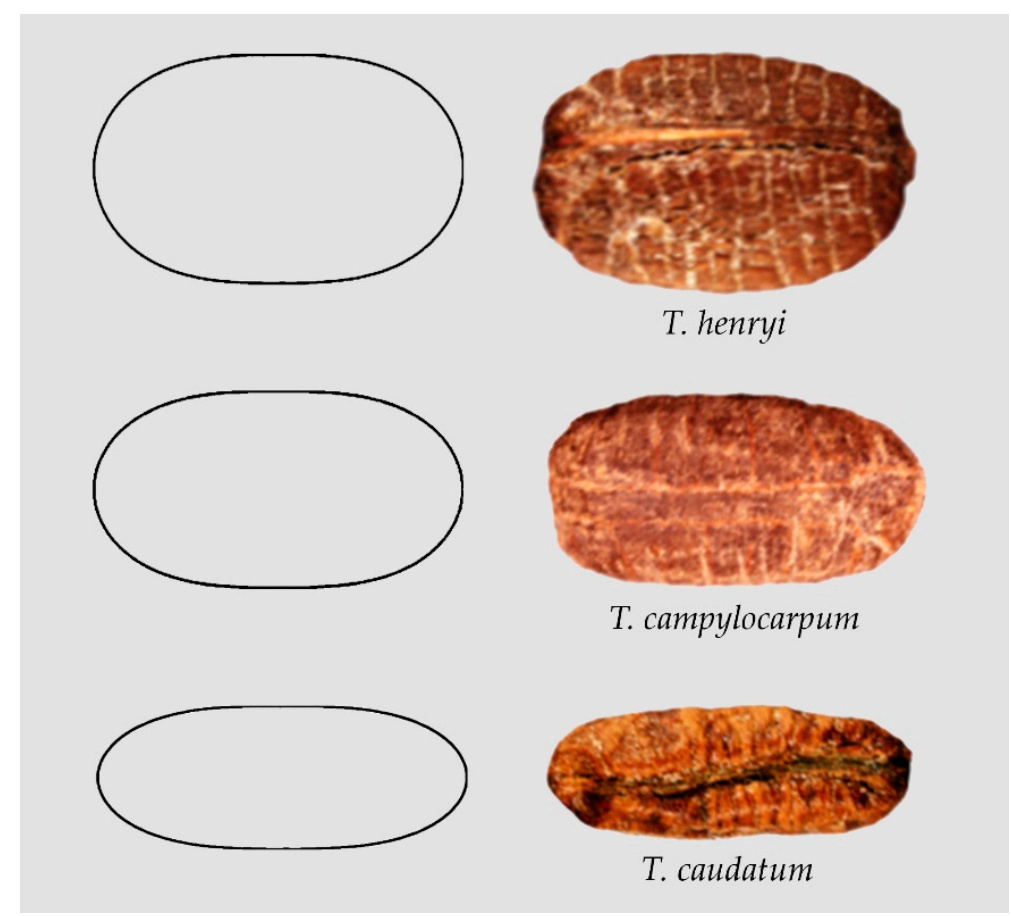

Figure 2. Examples of seed images resembling superellipses with different length/width ratios: First row: Tetrastigma henryi [51]. Second row: Tetrastigma campylocarpum [51]. Third row: T. caudatum [51].

Water drops and lemniscates described well the seeds of some species in the Arecaceae [13]. The former adapt well to the bi-dimensional shape of well-oriented images in the Vitaceae [45]. Figure 3 shows examples of seeds resembling elongated water drops, see [45] for quantitative measurements in Cissus verticillata.

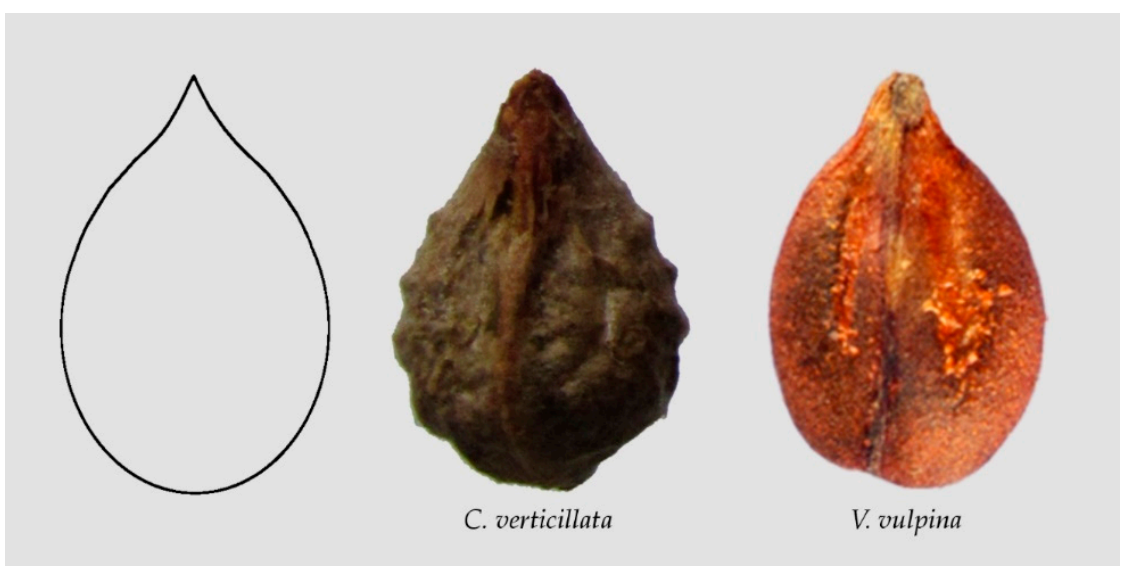

Figure 3. Examples of seed images resembling elongated water drops. From left to right: The model for an elongated water drop (Model 4 in [45]), seeds of Cissus verticillata and Vitis vulpina.

The equation describing the water drop is given in $[13,45]$, while the equation describing the lemniscate is given in [13]. 
3.2. Geometric Models for the Vitaceae: New Models Obtained from a Series of Equations Derived from an Ellipse

A family of equations will be described that simplify the design of new models according to the variety of seed types found in the Vitaceae [45]. The task of finding a model adapted to a new shape will be easier knowing which term of an existing equation may give the changes needed to obtain a given figure. With this objective, the equations corresponding to all models described in this section derive from the ellipse of equation:

$$
1-x^{2}-b^{2} y^{2}=0
$$

which can be expressed as:

$$
\left(\sqrt{1-x^{2}}-b y\right)\left(\sqrt{1-x^{2}}+b y\right)=0
$$

to remark the two explicit equations corresponding to the respective semi-ellipses that integrate it. Modifications in one of the factors, or in both, give equations of increasing complexity, whose graphic representations result in a variety of models.

A Water drop curve is obtained by the modification of Equation (2) to give:

$$
\left(\sqrt{1-x^{2}}+b y\right)\left(\sqrt{1-x^{2}}+\frac{a}{50 x^{2}+c}-b y\right)=0
$$

with $a=b=1, c=2$. While the semi-ellipse corresponding to the left factor has not changed, the factor on the right determines the prominent part of the drop (beak). Increasing the value of $a$, increases the size of the beak (See Data Availability Statement section).

\subsubsection{Water Drop Models}

The three models represented in Figure 4 result from changing the values of $a, b$ and $c$ and modifying other terms in Equation (2): Model VAM1 $(a=0.6 ; b=1 ; c=2)$ adjusts well to Vitis amurensis, V. labrusca, V. rupestris and Cissus granulosa; Model AGL1, a rounded Water drop, $(a=0.3 ; b=1.1 ; c=1.6)$ adjusts well to seeds of Ampelopsis glandulosa, Tetrastigma triphyllum and Cissus fuliginea; Model AAR1, an elongated Water drop, $(a=3 ; b=1 ; c=5)$ adjusts to seeds of Ampelopsis arborea, Cissus campestris and C. willardii (Data Availability Statement section). A slightly narrowed model adjusts well to seeds of Tetrastigma hensleyanum (not shown).

\subsubsection{Heart Curves}

Simultaneous modifications in both terms of Equation (2) result in a variety of heart curves. Heart curves are obtained with selected values of $a, b, c$ in:

$$
\left(\sqrt{1-x^{2}}-\frac{a}{54 x^{2}+9|x|+3}+y\right)\left(\sqrt{1-x^{2}}+\frac{b}{54 x^{2}+9|x|+3}-y\right)=0
$$

For example, Model ACO1 (see Figure 5) resulted from Equation (4) with $a=1 / 2$; $b=1 / 3$. Increasing $a$, reduces the size of the lower entry; increasing $b$, reduces the upper beak. 


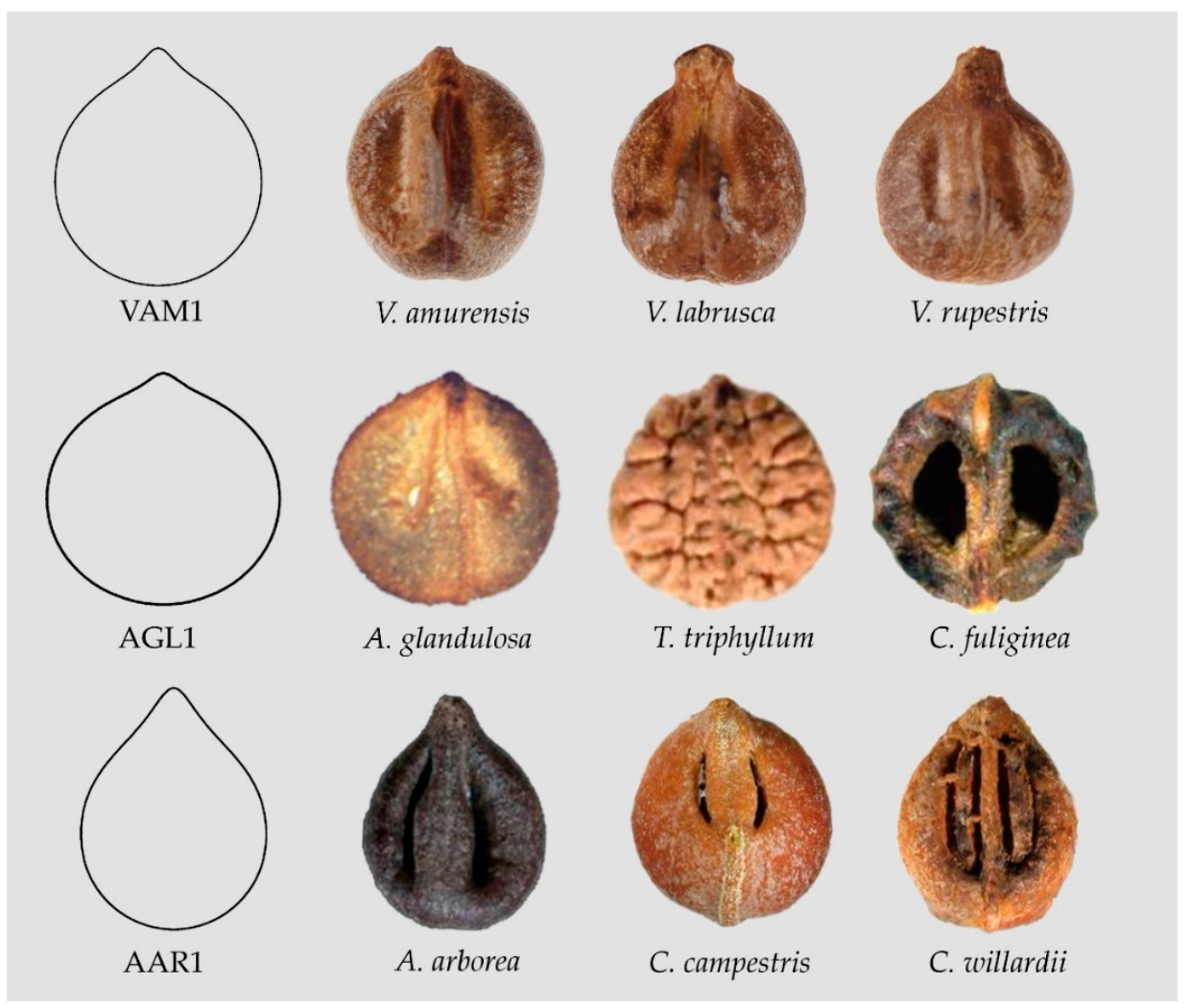

Figure 4. Seed images resembling water drops. From top to bottom: Model VAM1 (Vitis amurensis, V. labrusca, V. rupestris), Model AGL1 (Ampelopsis glandulosa, Tetrastigma triphyllum, Cissus fuliginea), Model AAR1 (Ampelopsis arborea, Cissus campestris, C. willardii).

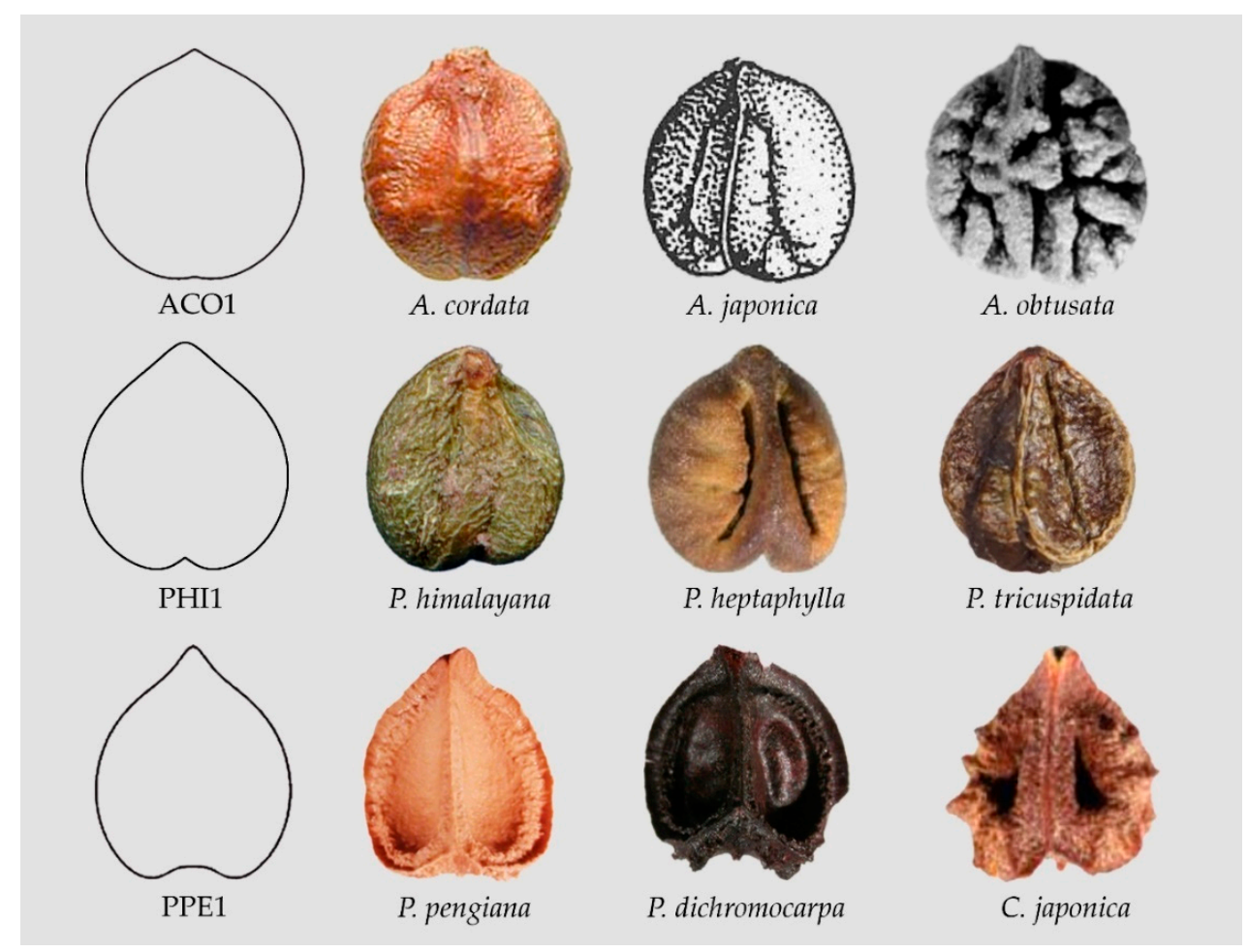

Figure 5. Seeds resembling heart curves. From top to bottom: Model ACO1 (Ampelopsis cordata, A. japonica, A. obtusata), Model PHI1 (Parthenocissus himalayana, P. heptaphylla, P. tricuspidata), Model PPE1 (Pseudocayratia pengiana, P. dichromocarpa, Cayratia japonica). 
Model PHI1 (see Figure 5) was obtained by the following modification in Equation (4):

$$
\left(\sqrt{1-x^{2}}+\frac{a}{10 x^{2}+1}-y\right)\left(\sqrt{1-x^{2}}-\frac{b}{54 x^{2}+9|x|+3}-y\right)=0
$$

with $a=1 / 3 ; b=1 / 2$.

Model PPE1 resulted from:

$$
\left(\sqrt{1-x^{2}}+\frac{a}{5 x^{4}+25 x^{2}+1}-\frac{9}{10} y\right)\left(\sqrt{1-x^{2}}-\frac{b}{5 x^{4}+25|x|^{3}+1}-\frac{9}{10} y\right)=0
$$

with $a=b=1 / 3$. (Data Availability Statement section).

Changes in the above equations give modified water drop and heart curves. For example, changes in Equation (3) result in broadened heart curves, giving (i) Models ARO1, AJA1 and AER1 that describe the seeds of Ampelocissus robinsonii, A. javalensis A. erdvendbergiana, respectively; and (ii) Models AGR1 and ADE1 that resemble the seeds of Ampelopsis grossdentata and A. denudata (AGR1) and A. delavayana and A. cantoniensis (ADE1) respectively, see Figure 6 and Data Availability Statement section. The significance of differences between apparently similar models, such as PPE1 and AGR1, can be tested quantitatively on samples with a sufficient number of seeds. In principle, the difference at the basis of the figures (more flat and with a plane entry in PPE1) justifies the separation of the two models.



Figure 6. Models of broadened heart curves and seeds resembling each of them in Ampelocissus and Ampelopsis. (Top): Model ARO1, Ampelocissus robinsonii, Model AJA1, Ampelocissus javalensis, Model AER1, A. erdvendbergiana. (Bottom): Model AGR1, Ampelopsis grossedentata, A. denudata; Model ADE1, A. delavayana, A. cantoniensis.

Departing from the models described, it is possible to find new figures specific for seeds in other species; for example, seeds of Ampelocissus cavicaulis, A. macrocirrha, and A. ochracea share with $A$. javalensis the Squared Heart Curve (SqHC) type related to Model AJA1. Other models, such as AGR2, may fit better the shape of seeds of A. grantii and A. latifolia (Figure 7). 


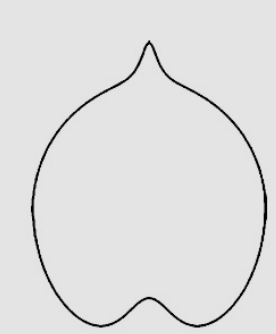

AJA1

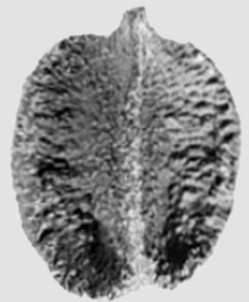

A. cavicaulis

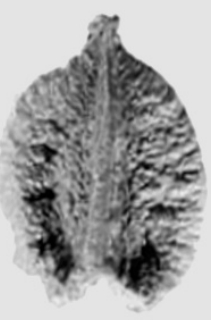

A. macrocirrha

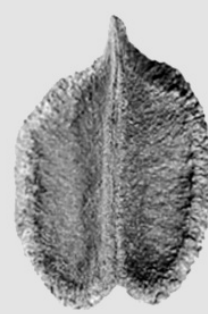

A. ochracea

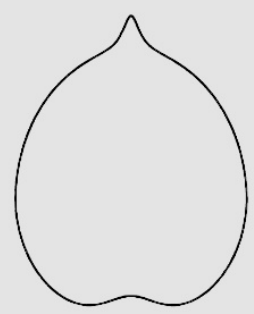

AGR2

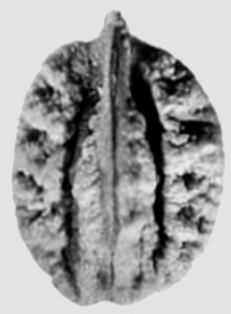

A. grantii

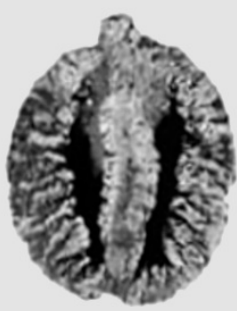

A. latifolia

Figure 7. The seeds of many species of Ampelocissus are related with the Squared Heart Curve (SqHC). Model AJA1 adapts well to Ampelocissus cavicaulis, A. macrocirrha and A. ochracea. Model AGR2 represents better the shape of seeds of A. grantii and A. latifolia.

\subsubsection{Pear Curves and Other Elongated Models}

Some seed images resemble water drops in their overall shape; nevertheless, they show broader basis than waterdrops. Figure 8 shows the models YAU1, COL1, VAE1 and AME1 that correspond respectively to the shapes of Yua austro-orientalis and Cissus trianae (YAU1), Cayratia oligocarpa (COL1), Yua chinensis and Vitis aestivalis (VAE1) and Ampelopsis megalophylla (AME1). These four models share similar values of aspect ratio that justify the inclusion of model COL1 here with preference to the Squared Heart Curve (SqHC) group. Seeds of some species of Ampelocissus (e.g., A. acapulcensis, A. bombycina, A. bravoi can fit either model COL1 or models derived from it (not shown)).

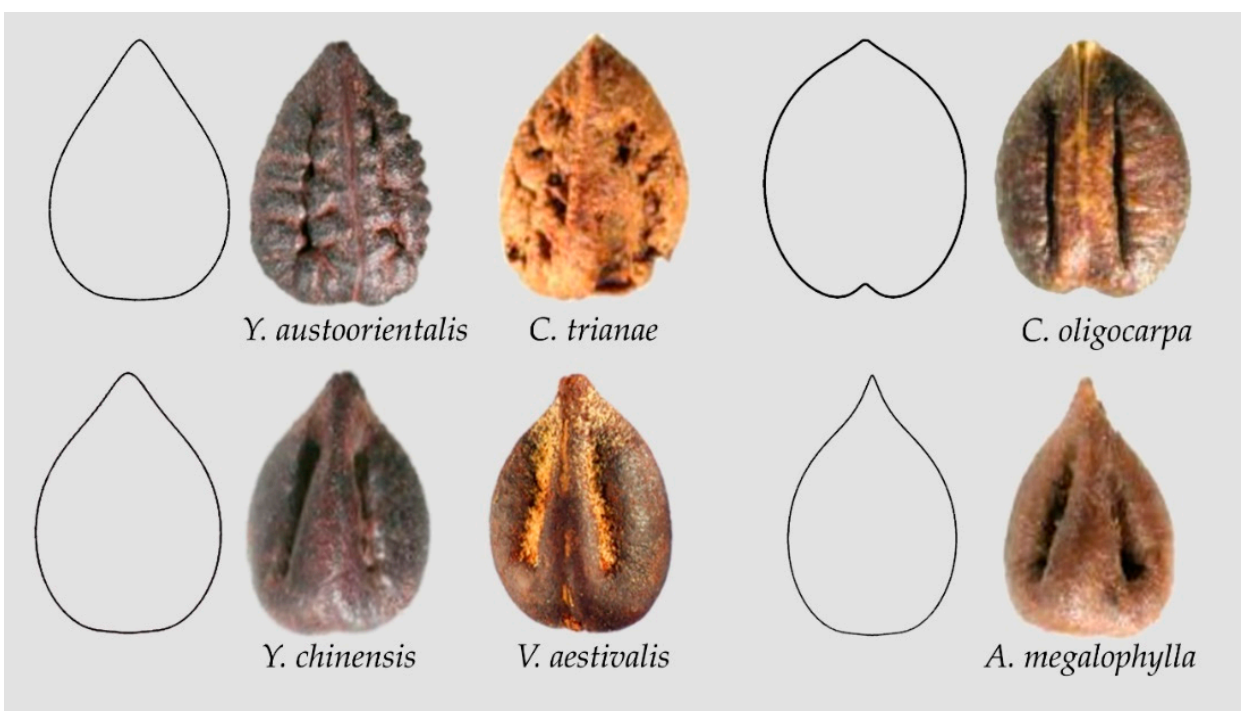

Figure 8. Models YAU1, COL1, VAE1 and AME1 with their respective seeds. Yua austro-orientalis and Cissus trianae (YAU1), Cayratia oligocarpa (COL1), Yua chinensis and Vitis aestivalis (VAE1) and Ampelopsis megalophylla (AME1). 
The seeds of Rhoicissus rhomboidea and of many species of Tetrastigma resemble polarized ellipses with an end bi-lobulated and the other acute. We have termed this morphological group as the Elongated Superellipse-Heart Curve (ESHC) (Figure 9).

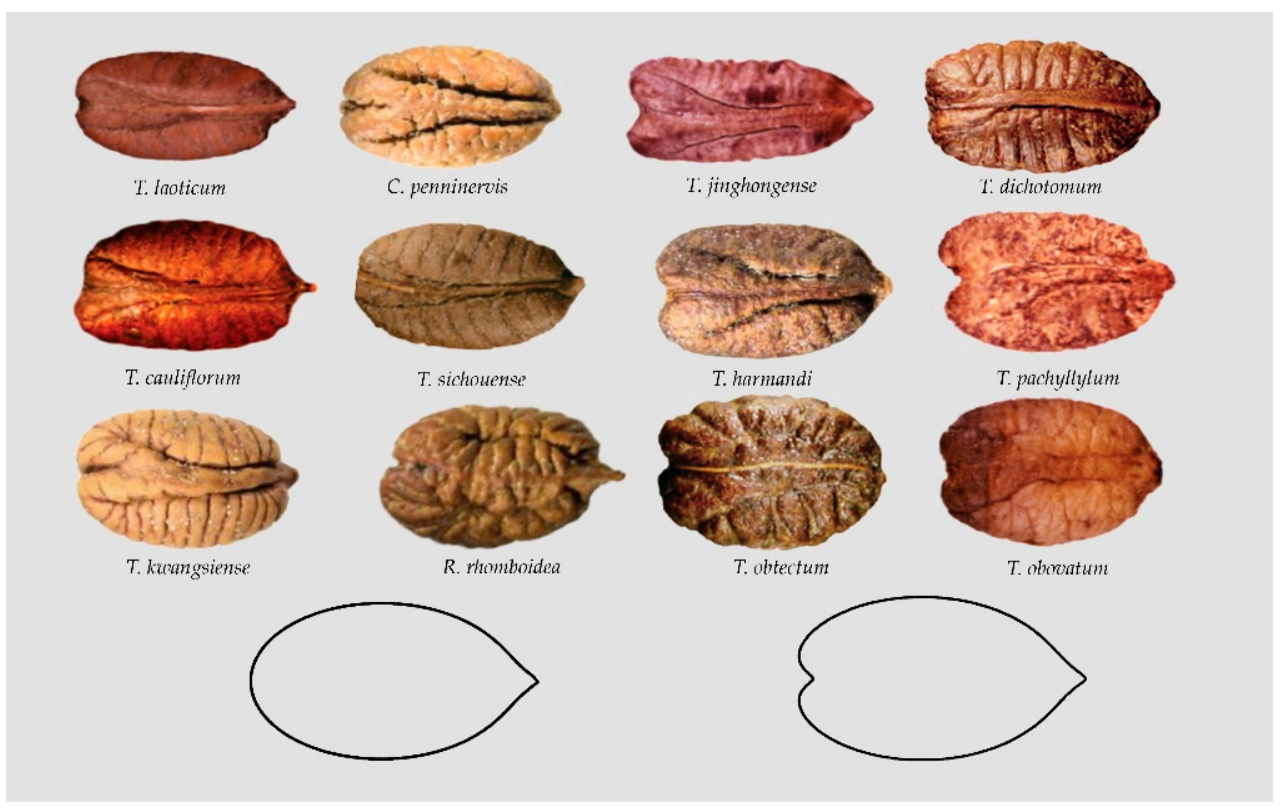

Figure 9. Seeds of Rhoicissus rhomboidea and many species of Tetrastigma resemble polarized ellipses with a side rounded or bi-lobulated and the other acute.

\subsection{A Summary of Geometric Types in Seeds of the Vitaceae}

Table 3 contains a summary of the morphological types for the Vitaceae according to the similarity of the seeds with geometrical figures. Ten morphological groups are described, three being present also in the Arecaceae [13] (lenses, superellipses and elongated water drops; termed respectively G I, G II and G III in Figure 10), three additional groups were described before for the Vitaceae [45] (water drops, heart curves and elongated heart curves; named G IV, G V and G VI in Figure 10), and four new groups are based on new models original from this work (G VII to G X). Three of the later models are particular for some genera and species. These are: (1) Heart curves of the Cayratia and Pseudocayratia types, with a marked entry at the basis and an acute protuberance (G VIII in Figure 10); (2) heart curves of the Squared Heart Curves (SqHCs) type in Ampelocissus and broadened models of Ampelocissus and Ampelopsis (G IX in Figure 10), and (3) Elongated SuperellipseHeart Curves (ESHCs), frequent in Tetrastigma species and observed also in Cissus species and R. rhomboidea (G X in Figure 10). 
Table 3. A summary of groups based on morphological seed types for the analysed species in the Vitaceae. The number of cases found in each group is given between dashes.

\begin{tabular}{cc}
\hline Group (Geometric Model) & Examples \\
\hline Group I (Lenses)-3- & Cissus quadrangularis [44], C. sterculiifolia [31], Tetrastigma petraeum [52] \\
\hline Group II (Superellipses)-7- & $\begin{array}{c}\text { Ampelocissus bravoi [42], C. reniformis [31,41], Cyphostemma elephantopus [49], C. } \\
\text { laza [31], Tetrastigma campylocarpum [52], T. caudatum [52], T. henryi [52] }\end{array}$ \\
Group III (Elongated water drops)-15- & $\begin{array}{c}\text { Ampelopsis arborea [37], Cayratia imerinensis [47], Cissus aralioides [35,40], } \\
\text { C. cornifolia [40], C. erosa [43], C. integrifolia [40,42], C. petiolata [40], C. pileata [40], } \\
\text { C. populnea [40], C. verticillata [31,41,42,45], C. sciaphila [40], C. smithiana [40], }\end{array}$ \\
\hline C. willardii [42], Cyphostemma junceum [31], V. vulpina [59,62]
\end{tabular}

Group IV (Water drops, normal or rounded)-14-

Group V (Heart curves normal or rounded)-19-
Ampelopsis bodinieri [36], A. glandulosa [36,39], A. humulifolia [36], Cayratia cheniana [46], Cissus campestris [31,41,42], C. fuliginea [31], C. tuberosa [42],

C. granulosa [31], Parthenocissus dalzielii [36], Tetrastigma triphyllum [31,52], Vitis amurensis [45,56], V. labrusca [45,54,59], V. palmata [60], V. rupestris [45]

Ampelopsis aconitifolia [36], A. chaffanjoni [36], A. cordata [38], A. japonica [36], Parthenocissus heptaphylla [31], P. heterophylla [36], P. henryana [36],

P. himalayana [52,53], P. quinquefolia [54], P. vitacea [31], P. tricuspidata [36,37,45], Rhoicissus revoilii [31], T. lanceolarium [30], Vitis cinerea [57], V. flexuosa [54], V. lanatoides [58], V. latisulcata [58], V. tsoi [31,41], V. wilsoniae [31,41] Ampelocissus acapulcensis [30], Cissus oligocarpa [31]. V. eolabrusca [54], V. grayensis [58], V. pseudorotundifolia [54], V. tiliifolia [61]
Group VI (Elongated Heart curves)-6-

Group VII (Other elongated types)-11-

Group VIII (Heart curves of the Cayratia and Pseudocayratia types)-7-

Group IX (Heart curves of the SqHC type of Ampelocissus and Ampelopsis)-15-

Group X Elongated Superellipse-heart curves-16-
Ampelopsis megalophylla [31,36], Causonis sp. [46], Cayratia saponaria [31], Cissus trianae [31], C. hypoglauca [31], Parthenocissus laetevirens [36], T. hypoglaucum [52] Vitis aestivalis [55], V. rotundifolia [31,41,54], Yua austro-orientalis [31], Y. chinensis [31]

Cayratia japonica [31,48], Cayratia sp. [African, [46]], Pseudocayratia

dichromocarpa [50], P. pengiana [50], P. speciosa [50,52], Tetrastigma formosanum [51], T. pedunculare $[31,51,52]$

Ampelocissus bombycina [30], A. cavicaulis [30], A. erdvendbergiana [30], A. grantii [30], A. javalensis [30,42], A. latifolia [30], A. macrocirrha [30], A. martinii [42], A. obtusata [30], A. ochracea [30], A. robinsonii [30], Ampelopsis cantoniensis [31,36], A. delavayana [31], A. denudata [30], A. grossedentata [31]

Cissus elongata [40], C. penninervis [31], Rhoicissus rhomboidea [31], Tetrastigma hemsleyanum [31,52], T. jinghongense [52], T. laoticum [52], T. cauliflorum [52], T. dichotomum [51], T. harmandi [31], T. pachyllylum [52], T. kwangsiense [30,31], T. obovatum [51,52], T. obtectum [51,52], T. retinervum [51], T. serrulatum [52], T. sichouense [52]

Cayratia geniculata [31], Cissus antarctica [31], C. barbeyana [40], C. bosseri [40], C. cactiformis [40], C. descoingsii, [31,41], C. diffusiflora [40], C. floribunda [40],

Undefined-18-
C. hastata [40], C. leucophlea [40], C. repens [40], C. subtetragona [40], T. delavayi [52],

T. rumicispermum [31,51,52], T. thorsborneorum [52], T. xishuangbannaense [31,52], V. brandoniana [54], V. rostrata [54]

In general, the distribution of morphological types is not in close agreement with the current taxonomic classification; nevertheless, some results may be summarized in this aspect. First, the seeds of the Elongated Superellipse-Heart Curves (ESHCs) type (Group $\mathrm{X}$ ) are more frequent in Tetrastigma and have been observed in Rhoicissus and Cissus, but not in species of other genera. While many seeds in species of Ampelopsis, Parthenocissus and Vitis share the typical shapes of water drop and heart curves, the squared heart curve (SqHC) type (Group IX) has been predominantly observed in Ampelocissus and Ampelopsis. A number of species remain undefined due to one of these two reasons: First, their irregular seed shape making difficult the identification of an adequate model (Cayratia geniculata, Cissus antarctica) and, second, the seed images have geometric shapes but the identification of the model with the corresponding equation is pending (Tetrastigma delavayi, T. rumicispermum). In addition, further work will be done on the seeds of Vitis species. 

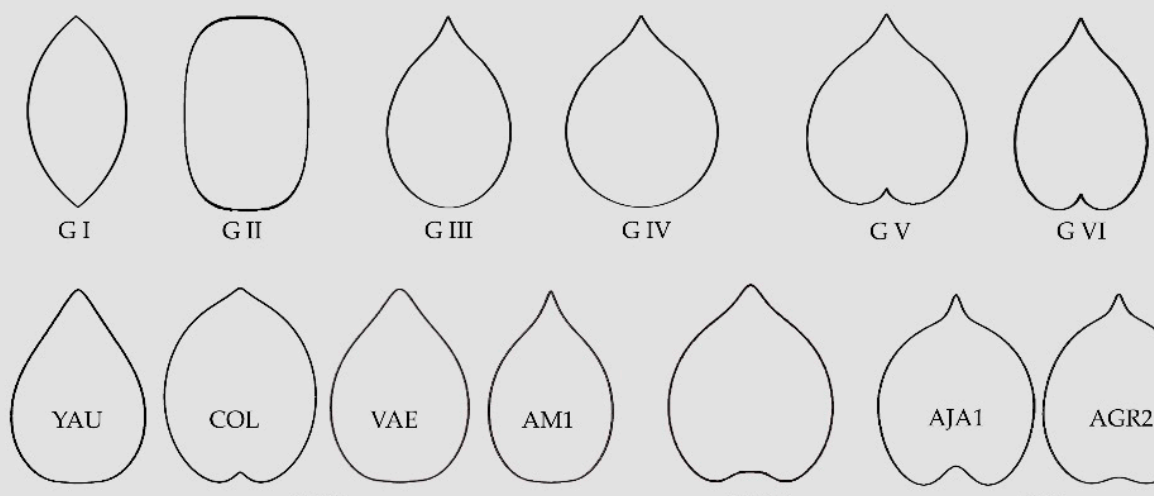

G VIII



GIX
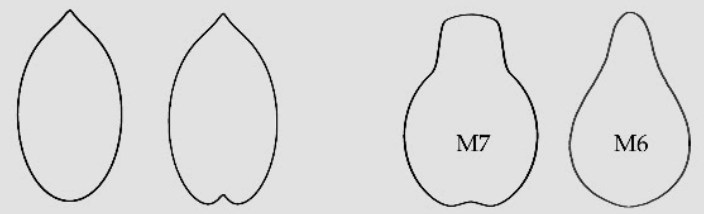

GX

Figure 10. A summary of the models found for the description and quantification of seed shape in the Vitaceae. G I, G II and G III are lenses, superellipses and elongated water drops, respectively; G IV, G V and G VI correspond to water drops, heart curves and elongated heart curves, respectively; G VII contains four models corresponding to other elongated curves; G VIII presents an example of the heart curves of the Cayratia and Pseudocayratia types; G IX, heart curves of the Squared Heart Curves (SqHCs) type in Ampelocissus and broadened models of Ampelocissus and Ampelopsis, and GX, Elongated Superellipse-Heart Curves (ESHCs), frequent in Tetrastigma species and observed also in Cissus species and R. rhomboidea. Labelled as M7 and M6 are two models used in the description of seeds of grape varieties and as precursors for other models [45,65].

\section{Discussion}

Morphology has not received the attention due in recent decades due to the increased emphasis on molecular approaches, but the importance of descriptive aspects is rising [68]. Seed morphology in particular may provide the basis for developments in Ecology and Evolution. The morphological analysis shows a similarity in seed shape between two families from the Core Angiosperms that are not related traditionally by taxonomic criteria: the Arecaceae and the Vitaceae. Both families belong to very different clades, the Vitaceae to the Eudicot clade and the Arecaceae to the Monocot clade $[1,6,69,70]$, and although the embryos of the former have two cotyledons and the latter have only one, their similarities in seed shape are in agreement with both families having endospermic seeds $[3,4,70]$. The seeds of the Arecaceae and the Vitaceae present a great diversity, including a combination of forms relatively infrequent in other plant families. Ellipses, ovals and cardioids are geometric forms frequent in plant families [18]; in contrast, superellipses are not so frequent. These adjust better to intermediate shapes between ellipses and rectangles. Other figures shared by the seeds of the Vitaceae and the Arecaceae are lenses and water drops of diverse proportions.

A distinctive aspect of seed morphology in the Vitaceae is the adjustment of their seeds to a diversity of water drops, heart curves and related figures. A series of variations derived from the equation of an ellipse have been described; their graphical representations give water drops and heart curves resembling with precision the seeds of diverse species of the Vitaceae. Both types of figures can be described as products from the modification of ellipses to obtain one pole acute and the other rounded or bi-lobulated.

The new models here described define the seed silhouettes of species in the diverse subfamilies of the Vitaceae. In addition to three groups based on models shared with the 
Arecaceae, and three other groups described before (water drops, heart curves, elongated heart curves) [45], four new groups have been described. One of them corresponds to other types of elongated curves, and the remaining three are more specific. These correspond to: (1) Heart curves of the Cayratia and Pseudocayratia types, with a marked entry at the basis and an acute protuberance; (2) heart curves of the Squared Heart Curves (SqHCs) type in Ampelocissus and broadened models of Ampelocissus and Ampelopsis, and (3) Elongated Superellipse-Heart Curves (ESHCs), frequent in Tetrastigma species and observed also in Cissus species and R. rhomboidea.

The importance of seed morphology in taxonomy has been described for a long time, see, for example, [71]. Nevertheless, not all characters of seed morphology have the same relevance, and, in many instances, the lack of a morphological diagnostic key may be due to a high degree of homoplasy [72,73]. The similarity of the seed silhouette to a geometric model is the result of a complex process of development, and thus less submitted to homoplasy; in consequence, it may be a good character in taxonomy. In addition, the visualization of geometric figures that share the form of seeds may contribute to their classification complementing the results of artificial vision techniques [74-76].

In addition to taxonomy, classification based on seed shape acquires relevance in other research areas. Members of both families, the Arecaceae and the Vitaceae, were present in the Neotropical flora in the Eocene [14], and their fruits have been in the human diet for a long time $[75,76]$. Additionally, both families have been studied by means of phytoliths, microfossils useful in archaeobotany and archaeology [77,78].

In the first paragraph of the introduction to his book entitled L'Évolution créatrice, Henri Bergson recognized the importance of Geometry stating that notre intelligence triomphe dans la géometrie, où se révelè la parenté de la pensée logique avec la matière inerte [79]. Unfortunately, in the following pages of this text, the author abandoned the study of geometry, a model of precision, to enter the rhetorics of evolution. An approach to seed geometry in palms and grapes could support the words of P.B. Tomlinson (1990): "Palms are not then merely emblematic of the tropics, they are emblematic of how the structural biology of plants must be understood before evolutionary scenarios can be reconstructed" [80], quoted in [69].

\section{Conclusions}

Ten morphological types are described in the Vitaceae. Seven of them are general and three specific. Among the general types, three are shared with the Arecaceae and correspond to geometric figures well described (lenses, superellipses and elongated waterdrops). Four additional groups include waterdrops, normal or rounded, heart curves, normal or rounded, elongated heart curves and other elongated curves, respectively. Finally, the three specific types correspond to heart curves of the Cayratia and Pseudocayratia types, heart curves of the Squared Heart Curve (SqHC) type of Ampelocissus and Ampelopsis, and Elongated Superellipse-Heart Curves (ESHCs), frequent in Tetrastigma species and observed also in Cissus species and R. rhomboidea. All these groups are defined by geometric models obtained by the representation of algebraic equations. Modifications in the equations result in models adjusting to the shape of seeds for each species.

Author Contributions: Conceptualization, E.C., Á.T.; methodology, E.C., J.J.M.-G., D.G.d.P., Á.T.; software, J.J.M.-G., Á.T.; validation, E.C., J.J.M.-G., D.G.d.P., Á.T.; formal analysis, E.C., J.J.M.-G., D.G.d.P., Á.T.; investigation, E.C., J.J.M.-G., D.G.d.P., Á.T.; resources, E.C., J.J.M.-G., D.G.d.P., Á.T.; data curation, J.J.M.-G.; writing—original draft preparation, E.C.; writing—review and editing, E.C., J.J.M.-G., D.G.d.P., Á.T.; visualization, J.J.M.-G. All authors have read and agreed to the published version of the manuscript.

Funding: Project "CLU-2019-05-IRNASA/CSIC Unit of Excellence", funded by the Junta de Castilla y León and co-financed by the European Union (ERDF "Europe drives our growth").

Data Availability Statement: The Mathematica code for Geometric Models is given in: https:// zenodo.org/record/4942111\#.YMbkrfkzaM8.

Conflicts of Interest: The authors declare no conflict of interest. 


\section{References}

1. The Angiosperm Phylogeny Group; Chase, M.W.; Christenhusz, M.J.; Fay, M.F.; Byng, J.W.; Judd, W.S.; Soltis, D.E.; Mabberley, D.J.; Sennikov, A.N.; Soltis, P.S.; et al. An update of the Angiosperm Phylogeny Group classification for the orders and families of flowering plants: APG IV. Bot. J. Linn. Soc. 2016, 181, 1-20. [CrossRef]

2. Ridsdale, C.E. A revision of the family Leeaceae. Blumea 1974, 22, 57-100.

3. Wen, J.; Lu, L.-M.; Nie, Z.-L.; Liu, X.-Q.; Zhang, N.; Ickert-Bond, S.; Gerrath, J.; Manchester, S.R.; Boggan, J.; Chen, Z.-D. A new phylogenetic tribal classification of the grape family (Vitaceae). J. Syst. Evol. 2018, 56, 262-272. [CrossRef]

4. Zhang, N.; Wen, J.; Zimmer, E.A. Congruent deep relationships in the grape family (Vitaceae) based on sequences of chloroplast genomes and mitochondrial genes via genome skimming. PLOS ONE 2015, 10, e0144701.

5. Zeng, L.P.; Zhang, N.; Zhang, Q.; Endress, P.K.; Huang, J.; Ma, H. Resolution of deep eudicot phylogeny and their temporal diversification using nuclear genes from transcriptomic and genomic datasets. New Phytol. 2017, 214, 1338-1354. [CrossRef] [PubMed]

6. Wen, J. Vitaceae. In The Families and Genera of Vascular Plants; Kubitzki, K., Ed.; Springer: Berlin, Germany, 2007 ; pp. 467-479.

7. Planchon, J.E. Monographie des Ampélidées vrais. In Monographiae Phanaerogamarum 5; de Candolle, A.P., de Candolle, A.C.P., Eds.; Masson: Paris, France, 1887; pp. 305-654.

8. Rossetto, M.; Jackes, B.R.; Scott, K.D.; Henry, R.J. Is the genus Cissus (Vitaceae) monophyletic? Evidence from Plastid and Nuclear Ribosomal DNA. Syst. Bot. 2002, 27, 522-533. [CrossRef]

9. Hearn, D.J.; Evans, M.; Wolf, B.; McGinty, M.; Wen, J. Dispersal is associated with morphological innovation, but not increased diversification, in Cyphostemma (Vitaceae). J. Syst. Evol. 2018, 56, 340-359. [CrossRef]

10. Terral, J.F.; Tabard, E.; Bouby, L.; Ivorra, S.; Pastor, T.; Figueiral, I.; Picq, S.; Chevance, J.-B.; Jung, C.; Fabre, L.; et al. Evolution and history of grapevine (Vitis vinifera) under domestication: New morphometric perspectives to understand seed domestication syndrome and reveal origins of ancient European cultivars. Ann. Bot. 2010, 105, 443-455. [CrossRef]

11. This, P.; Lacombe, T.; Thomas, M.R. Historical origins and genetic diversity of wine grapes. Trends Genet. 2006, 22, 511-519. [CrossRef]

12. Encyclopedia Britannica. Vitales. Available online: https://www.britannica.com/plant/Vitales (accessed on 25 July 2021).

13. Gutiérrez del Pozo, D.; Martín-Gómez, J.J.; Tocino, Á.; Cervantes, E. Seed geometry in the Arecaceae. Horticulturae 2020, 6, 64. [CrossRef]

14. Herrera, F.; Manchester, S.R.; Jaramillo, C. Permineralized fruits from the late Eocene of Panama give clues of the composition of forests established early in the uplift of Central America. Rev. Palaeobot. Palynol. 2012, 175, 10-24. [CrossRef]

15. Schneider, C.A.; Rasband, W.S.; Eliceiri, K.W. NIH Image to ImageJ: 25 years of image analysis. Nat. Methods 2012, 9, 671-675. Available online: http:/ /imagej.nih.gov/ij/docs/guide (accessed on 20 January 2021). [CrossRef] [PubMed]

16. Cervantes, E.; Martín-Gómez, J.J.; Saadaoui, E. Updated methods for seed shape analysis. Scientifica 2016, 5691825. [CrossRef] [PubMed]

17. Cervantes, E.; Martín-Gómez, J.J. Seed shape description and quantification by comparison with geometric models. Horticulturae 2019, 5, 60. [CrossRef]

18. Cervantes, E.; Martín-Gómez, J.J.; del Pozo, D.G.; Silva Días, L. An angiosperm species dataset reveals relationships between seed size and two-dimensional shape. Horticulturae 2019, 5, 71. [CrossRef]

19. Cervantes, E.; Martín-Gómez, J.J.; Ardanuy, R.; de Diego, J.G.; Tocino, Á. Modeling the Arabidopsis seed shape by a cardioid: Efficacy of the adjustment with a scale change with factor equal to the Golden Ratio and analysis of seed shape in ethylene mutants. J. Plant. Physiol. 2010, 167, 408-410. [CrossRef] [PubMed]

20. Martín Gómez, J.J.; Tocino, Á.; Ardanuy, R.; de Diego, J.G.; Cervantes, E. Dynamic analysis of Arabidopsis seed shape reveals differences in cellulose mutants. Acta Physiol. Plant. 2014, 36, 1585-1592. [CrossRef]

21. Cervantes, E.; Martín-Gómez, J.J.; Chan, P.K.; Gresshoff, P.M.; Tocino, Á. Seed shape in model legumes: Approximation by a cardioid reveals differences in ethylene insensitive mutants of Lotus japonicus and Medicago truncatula. J. Plant Physiol. 2012, 169, 1359-1365. [CrossRef]

22. Saadaoui, E.; Martín-Gómez, J.J.; Cervantes, E. Intraspecific variability of seed morphology in Capparis spinosa L. Acta Biol. Cracov. Bot. 2013, 55, 99-106. [CrossRef]

23. Saadaoui, E.; Martín-Gómez, J.J.; Tlili, N.; Khaldi, A.; Cervantes, E. Effect of climate in seed diversity of wild Tunisian Rhus tripartita (Ucria) Grande. J. Adv. Biol. Biotechnol. 2017, 13, 1-10. [CrossRef]

24. Martín-Gómez, J.J.; Saadaoui, E.; Cervantes, E. Seed shape of castor bean (Ricinus communis L.) grown in different regions of Tunisia. J. Agric. Ecol. Res. Int. 2016, 8, 1-11.

25. Saadaoui, E.; Martín, J.J.; Bouazizi, R.; Chokri, B.R.; Grira, M.; Abdelkabir, S.; Khouja, M.L.; Cervantes, E. Phenotypic variability and seed yield of Jatropha curcas L. introduced to Tunisia. Acta Botánica Mex. 2015, 110, 119-134. [CrossRef]

26. Martín-Gómez, J.J.; Rewicz, A.; Goriewa-Duba, K.; Wiwart, M.; Tocino, Á.; Cervantes, E. Morphological description and classification of wheat kernels Based on geometric models. Agronomy 2019, 9, 399. [CrossRef]

27. Cervantes, E.; Martín-Gómez, J.J. Seed shape quantification in the order Cucurbitales. Mod. Phytomorphol. 2018, 12, 1-13. [CrossRef]

28. Martín-Gómez, J.J.; Rewicz, A.; Cervantes, E. Seed shape diversity in families of the order Ranunculales. Phytotaxa 2019, 425, 193-207. [CrossRef] 
29. Martín-Gómez, J.J.; del Pozo, D.G.; Cervantes, E. Seed shape quantification in the Malvaceae reveals cardioid-shaped seeds predominantly in herbs. Botanica 2019, 25, 21-31. [CrossRef]

30. Chen, I.; Manchester, S.R. Seed morphology of modern and fossil Ampelocissus (Vitaceae) and implications for phytogeography. Am. J. Bot. 2007, 94, 1534-1553. [CrossRef] [PubMed]

31. Chen, I.; Manchester, S.R. Seed morphology of Vitaceae. Int. J. Plant. Sci. 2011, 172, 1-35. [CrossRef]

32. Corner, E.J.H. The Seeds of Dicotyledons; Cambridge University Press: Cambridge, UK, 1976; Volume 1.

33. Trias-Blasi, A.; Parnell, J.A.N.; Chayamarit, K. Cissus amplexicaulis (Vitaceae), a new endemic species from Thailand. Kew Bull. 2010, 65, 487-490. [CrossRef]

34. Kew Science. Plants of the World Online. Cissus aphylla Chiov. Available online: http://powo.science.kew.org/taxon/urn:lsid: ipni.org:names:869770-1 (accessed on 9 July 2021).

35. Kew Science. Plants of the World Online. Cissus aralioides (Welw. ex Baker) Planch. Available online: http:/ / powo.science.kew. org/taxon/urn:lsid:ipni.org:names:67514-1 (accessed on 9 July 2021).

36. Latiff, A. Studies in Malesian Vitaceae VII. The genus Tetrastigma in the Malay Peninsula. Gard. Bull. Singap. 1984, 36, 213-228.

37. Manchester, S.R.; Kapgate, D.K.; Wen, J. Oldest fruits of the grape family (Vitaceae) from the Late Cretaceous Deccan Cherts of India. Am. J. Bot. 2013, 100, 1849-1859. [CrossRef] [PubMed]

38. Native Plant Trust: Go Botany. Ampelopsis cordata Michx. Available online: https://gobotany.nativeplanttrust.org/species/ ampelopsis/cordata/ (accessed on 9 July 2021).

39. Norfolk Cottage Garden Seeds \& Plants. Ampelopsis glandulosa var. Brevipedunculata. Available online: https://www. norfolkcottagegarden.co.uk/images/seeds/macro/ampelopsis-glandulosa-var-brevipedunculata_seed-macro_img148_960px. jpg (accessed on 9 July 2021).

40. Adams, N.F.; Collinson, M.E.; Smith, S.Y.; Bamford, M.K.; Forest, F.; Malakasi, P.; Marone, F.; Sykes, D. X-rays and virtual taphonomy resolve the first Cissus (Vitaceae) macrofossils from Africa as early-diverging members of the genus. Am. J. Bot. 2016, 103, 1657-1677. [CrossRef] [PubMed]

41. Chen, I. History of Vitaceae Inferred from Morphology-Based Phylogeny and the Fossil Record of Seeds. Ph.D. Thesis, University of Florida, Gainesville, FL, USA, 2009.

42. Manchester, S.R.; Chen, I.; Lot, T.A. Seeds of Ampelocissus, Cissus and Leea (Vitales) from the Paleogene of Western Peru and their Biogeographic significance. Int. J. Plant. Sci. 2012, 173, 933-943. [CrossRef]

43. Smithsonian Tropical Research Institute. Cissus Erosa Subsp Erosa. Available online: https://biogeodb.stri.si.edu/bioinformatics/ $\mathrm{dfm} / \mathrm{metas} /$ view / 7894 (accessed on 9 July 2021).

44. DELTA-Description Language for Taxonomy. Cissus quadrangularis. Available online: https://www.delta-intkey.com/famfs/ images/vitace03.jpg (accessed on 9 July 2021).

45. Martín-Gómez, J.J.; Gutiérrez del Pozo, D.; Ucchesu, M.; Bacchetta, G.; Cabello Sáenz de Santamaría, F.; Tocino, Á.; Cervantes, E. Seed morphology in the Vitaceae based on geometric models. Agronomy 2020, 10, 739. [CrossRef]

46. Lu, L.; Wen, J.; Chen, Z. Cayratia cheniana (Vitaceae): An endangered new species endemic to the limestone mountains of Ninh Thuan Province, Vietnam. Syst. Bot. 2016, 41, 49-55. [CrossRef]

47. Descoings, B. Flore de Madagascar et des Comores (Plantes Vasculaires) 124 Famille-Vitacées; Museum National d'Histoire Naturelle: Paris, France, 1967. Available online: https:/ / www.delta-intkey.com/angio/images/cayratia.gif (accessed on 9 July 2021).

48. Jiang, H.; Yang, J.; Liang, T.; Zhang, Z.; Wang, S.; Qi, X.; Sheng, P. Palaeoethnobotanical analysis of plant remains discovered in the graveyard of the Haihun Marquis, Nanchang, China. Veg. Hist. Archaeobot. 2021, 30, 119-135. [CrossRef]

49. The World of Plants: Cyphostemma elephantopus. Available online: https://public.fotki.com/PanosS/vitaceae-pages/ cyphostemma / cyphostema_elephant.html (accessed on 9 July 2021).

50. Wen, J.; Lu, L.-M.; Hsu, T.-W.; Dang, V.-C.; Habib, S.; Boggan, J.K.; Okada, H.; Chen, I.-J.; Chen, Z.-D. Pseudocayratia, a new genus of Vitaceae from China and Japan with two new species and three new combinations. J. Syst. Evol. 2018, 56, 374-393. [CrossRef]

51. Habib, S.; Dang, V.-C.; Ickert-Bond, S.M.; Wen, J.; Chen, Z.-D.; Lu, L.-M. Evolutionary trends in Tetrastigma (Vitaceae): Morphological diversity and taxonomic implications. J. Syst. Evol. 2018, 56, 360-373. [CrossRef]

52. Habib, S.; Dang, V.-C.; Ickert-Bond, S.M.; Zhang, J.-L.; Lu, L.-M.; Wen, J.; Chen, Z.-D. Robust phylogeny of Tetrastigma (Vitaceae) based on ten plastid DNA regions: Implications for infrageneric classification and seed character evolution. Front. Plant. Sci. 2017, 8, 590. [CrossRef]

53. Norfolk Cottage Garden Seeds and Plants. Parthenocissus himalayana. Available online: https://www.norfolkcottagegarden.co. uk/images/seeds/macro/parthenocissus-himalayana-syn-semicordata_seed-macro_518_960px.jpg (accessed on 9 July 2021).

54. Tiffney, B.H.; Barghoorn, E.S. Fruits and seeds of the Brandon lignite. I. Vitaceae. Rev. Palaeobot. Palynol. 1976, $22,169-191$. [CrossRef]

55. Plants USDA. Vitis aestivalis. Available online: https://plants.sc.egov.usda.gov/home/plantProfile?symbol=VIAE (accessed on 9 July 2021).

56. Kirkbride, J.H., Jr.; Gunn, C.R.; Dallwitz, M.J. 2000 Onwards. Family Guide for Fruits and Seeds: Descriptions, Illustrations, Identification, and Information Retrieval; Version: 12th April 2021. Available online: https://www.delta-intkey.com/famfs/ images/vitace04.jpg. (accessed on 9 July 2021).

57. Plants USDA. Vitis cinerea. Available online: https:// plants.sc.egov.usda.gov/home/plantProfile?symbol=VICI2 (accessed on 9 July 2021). 
58. Gong, F.; Karsai, I.; Liu, Y.-S. Vitis seeds (Vitaceae) from the late Neogene Gray Fossil Site, northeastern Tennessee, USA. Rev. Palaeobot. Palynol. 2010, 162, 71-83. [CrossRef]

59. Ardenghi, N.M.G.; Galasso, G.; Banfi, E.; Cauzzi, P. Vitis $\times$ novae-angliae (Vitaceae): Systematics, distribution and history of an "illegal" alien grape in Europe. Willdenowia 2015, 45, 197-207. [CrossRef]

60. Plants USDA. Vitis palmata. Available online: https://plants.sc.egov.usda.gov/home/plantProfile?symbol=VIPA7 (accessed on 9 July 2021).

61. Smithsonian Tropical Research Institute. Vitis tiliifolia. Available online: https://biogeodb.stri.si.edu/bioinformatics/dfm/metas/ view /10813? \&lang=es (accessed on 9 July 2021).

62. Plants USDA. Vitis vulgaris. Available online: https://plants.sc.egov.usda.gov/home/plantProfile?symbol=VIVU (accessed on 9 July 2021).

63. Weisstein, E.W. "Heart Curve." From MathWorld-A Wolfram Web Resource. Available online: http:/ / mathworld.wolfram. com/HeartCurve.html (accessed on 19 May 2021).

64. Weisstein, E.W. “Pear Curve.” From MathWorld-A Wolfram Web Resource. Available online: http:/ / mathworld.wolfram.com/ PearCurve.html (accessed on 19 May 2021).

65. Cervantes, E.; Martín-Gómez, J.J.; Espinosa-Roldán, F.E.; Muñoz-Organero, G.; Tocino, Á.; Cabello-Sáenz de Santamaría, F. Seed morphology in key Spanish grapevine cultivars. Agronomy 2021, 11, 734. [CrossRef]

66. Gielis, J. A generic geometric transformation that unifies a wide range of natural and abstract shapes. Am. J. Bot. 2003, 90, 333-338 [CrossRef]

67. Gridgeman, N.T. Lamé Ovals. Math. Gaz. 1970, 54, 31-37. [CrossRef]

68. Christodoulou, M.D.; Clark, J.Y.; Culham, A. The Cinderella discipline: Morphometrics and their use in botanical classification. Bot. J. Linn. Soc. 2020, 194, 1-12. [CrossRef]

69. Judd, W.S.; Campbell, C.S.; Kellogg, E.A.; Stevens, P.F.; Donoghue, M.J. Plant Systematics: A Phylogenetic Approach, 2nd ed.; Sinauer Assoc.: Sunderland, MA, USA, 2002.

70. Dransfield, J.; Uhl, N.W.; Asmussen, C.B.; Baker, W.J.; Harley, M.M.; Lewis, C.E. Genera Palmarum: The Evolution and Classification of Palms; Kew Publishing; Royal Botanic Gardens of Kew: Kew, UK, 2008.

71. Rohrbach, P. Monographie der Gattung Silene; Verlag von Engelmann: Leipzig, Germany, 1869; pp. 1-249.

72. Jafari, F.; Zarre, S.; Gholipour, A.; Eggens, F.; Rabeler, R.K.; Oxelman, B. A new taxonomic backbone for the infrageneric classification of the species-rich genus Silene (Caryophyllaceae). Taxon 2020, 69, 337-368. [CrossRef]

73. Martín-Gómez, J.J.; Rewicz, A.; Rodríguez-Lorenzo, J.L.; Janoušek, B.; Cervantes, E. Seed morphology in Silene based on geometric models. Plants 2020, 9, 1787. [CrossRef]

74. Milanesi, C.; Costantini, L.; Firmati, M.; Antonucci, F.; Faleri, C.; Buracchi, A.; Cresti, M. Geometric morphometry and archaeobotany: Characterisation of grape seeds (Vitis vinifera L.) by analysis of form. Open Access Libr. J. 2014, 1, e634. [CrossRef]

75. Ucchesu, M.; Orrú, M.; Grillo, O.; Venora, G.; Paglietti, G.; Ardu, A.; Bacchetta, G. Predictive method for correct identification of archaeological charred grape seeds: Support for advances in knowledge of grape domestication process. PLoS ONE 2016, 11, e0149814. [CrossRef]

76. Ucchesu, M.; Orrú, M.; Grillo, O.; Venora, G.; Usai, A.; Serreli, P.F.; Bacchetta, G. Earliest evidence of a primitive cultivar of Vitis vinifera L. during the Bronze Age in Sardinia (Italy). Veg. Hist. Archaeobotany 2015, 24, 587-600. [CrossRef]

77. Morcote-Ríos, G.; Bernal, R.; Raz, L. Phytoliths as a tool for archaeobotanical, palaeobotanical and palaeoecological studies in Amazonian palms. Bot. J. Linn. Soc. 2016, 182, 348-360. [CrossRef]

78. Sharma, R.; Kumar, V.; Kumar, R. Distribution of phytoliths in plants: A review. Geol. Ecol. Landsc. 2019, 3, 123-148. [CrossRef]

79. Bergson, H. L'Évolution Créatrice. Édition Electronique (ePub, PDF) v.: 1.0: Les Échos du Maquis, avril 2013. Available online: https://philosophie.cegeptr.qc.ca/wp-content/documents/L\%C3\%A9volution-cr\%C3\%A9atrice.pdf (accessed on 16 August 2021).

80. Tomlinson, P.B. The Structural Biology of Palms; Clarendon Press: Oxford, UK, 1990. 